\title{
KELLE EMOTSIOONILE ANDA TEKSTI ETTE LUGEDES HÄAL? VAATLUS MITMEST PERSPEKTIIVIST
}

\author{
Ene Vainik
}

\begin{abstract}
Ülevaade. Artikli eesmärgiks on esile tuua, milliste inimloomusest tulenevate tõsiasjadega peaks arvestama, kui on plaanis hakata sünteeskõnele emotsioone matkivat prosoodiat lisama. Sel eesmärgil on kokku koondatud lähenemised erinevatest inimest puudutavatest teadusharudest nagu neuroloogia, kirjandusteadus, sotsiaalpsühholoogia, filosoofia jne. Eri perspektiividena käsitletakse kuulaja, teksti peategelase, autori ja lugeja emotsioonide kujunemist. Seejärel kirjeldatakse, kuidas lisab vokaalseid emotsioone inimesest ettelugeja ning kuidas lähenetakse teksti ja emotsioonide vahekorrale afektirehkenduse valdkonnas. Artikli lõpuosas esitatakse visioon keskmise lugeja emotsionaalset reageeringut jäljendavast virtuaalsest Emonculus'est kui võimalikust tulevikuperspektiivist emotsionaalse prosoodia lisamisel sünteeskõnele.*
\end{abstract}

Võtmesõnad: kirjalik tekst, sünteeskõne, emotsioonid, afektirehkendus, perspektiivide mitmekesisus, eesti keel

\begin{abstract}
Ajal, mil paljud tehnoloogilised seadmed kannavad austavat täiendit nuti (-telefon, -TV), on õigustatud ootus, et ka kirjalikku teksti ettelugev kõnesüntesaator oleks mingil määral nutikas. Tahame, et ta oskaks aru saada, kas tegu on formaalsema või isiklikuma tekstiga, ning loeks teksti ette inimesega võimalikult sarnasel viisil - seal, kus kohane, mõningase emotsionaalse kaasaelamisega (vt nt Mihkla jt 2012). Selle üle, kas ja kuidas on arvutil võimalik kirjalike tekstilausete seast emotsionaalselt laetuid ära tunda, on arutletud mujal ja uurimistööd selles suunas pole kaugeltki lõpetatud (vt nt Vainik 2010, 2012a ja 2012b). Siinses käsitluses pakub huvi eelkõige küsimus, kelle emotsioonile anda teksti ette lugedes hääl? Kas inimliku emotsionaalsuse jäljendamiseks sünteeskõnes tuleks luua mulje, et kõneleb teksti autor, vahendada teksti keskse tegelase emotsionaalset seisundit või anda hääl hoopis kellelegi kolmandale? Vastuse otsimisel lähtutakse seisukohast, et enne, kui hakata
\end{abstract}

* Uurimust on toetanud sihtrahastus "Eesti keele alusuuringud keeletehnoloogiliste rakenduste teenistuses" 
mingit inimlikku omadust arvutile õpetama, on kasulik võimalikult põhjalikult välja uurida, mida on selle nähtuse kohta juba teada saadud inimest uurides.

Selle kohta, kuidas inimesed lugemise käigus mõistavad teksti ja selle sees või taga paiknevate isikute emotsioone, ning mida nad seejuures ise emotsionaalselt läbi elavad, on kirjutatud palju ja mõistetavalt eri distsipliinide raames (kirjandusteadus, psühholoogia, filosoofia). Kuna tegemist on kahtlemata kompleksse ja mitmetahulise probleemistikuga, on käesolevas käsitluses mindud selle eri perspektiividena eritlemise teed. Esimese perspektiivina vaadeldakse küsimust, kas psühholoogiliselt realistlik prosoodia on üldse tarvilik lõpptarbija, st etteloetava teksti kuulaja, seisukohast ja milliste inimese loomusest tulenevate asjaoludega seda põhjendatakse. Teise perspektiivina tuuakse esile tekstist endast tulenevad võimalused keskendada tähelepanu kas teksti peategelase või siis autori emotsioonidele. Kolmas perspektiiv heidab valgust sellele, mida on arvatud teksti lugeja emotsioonide kujunemise kohta. Neljanda perspektiivina vaadeldakse ettelugemise situatsiooni tavainimesest ettelugeja positsiooni silmas pidades ning viiendana esitatakse n-ö arvuti perspektiiv. Käsitluse käigus võrreldakse teoreetilistes allikates kirjapandut mõningal määral ka Eesti emotsionaalse kõne korpuse ${ }^{1}$ koostamisel saadud empiiriliste tulemustega ja lähenemisega teksti emotsionaalsuse määramisele (nt Altrov 2007, 2008, Pajupuu jt 2012). Lõpuosas arutletakse tulevikuperspektiivide üle ja esitatakse kokkuvõte ning järeldus.

\section{Kuulaja perspektiiv}

Kas ja miks peaks kõnesüntesaator teksti ette lugedes üldse püüdma inimlikku emotsionaalsust jäljendada? Üks vastuseid tuleneb sellest, et meie kuulmismeel on kohanenud jälgima ja tõlgendama eelkõige spontaanseid lausungeid. Loomulikus kõnesituatsioonis kaasneb verbaalse sõnumiga detailidest rikas situatiivne kontekst, mis pakub tuge kuuldu interpreteerimiseks. Kirjaliku teksti ettelugemine erineb loomulikust suhtlusest mitte üksnes lausete varieeruva pikkuse ja komplekssuse poolest, vaid ka selle poolest, et loomulikust multimodaalsest suhtlussituatsioonist jääb toimima ainult auditiivne ülekandekanal, seda eriti olukordades, kus ettelugemine toimub mitte näost näkku, vaid mingi seadme vahendusel (nt raadio, audioraamat). Seetõttu tundub otstarbekas, et auditiivsel kanalil esitatav sõnum kompenseeriks mingil määral vahetus suhtlusolukorras esinevaid visuaalseid infoallikaid, näiteks kõneleja näoilmet või kehaasendit, mis annavad tihti märku just kõneleja emotsionaalsest seisundist.

Lisaks intuitiivsele inimsarnasuse eelistusele räägivad emotsioonide jäljendamise kasuks ka uurimused, mis on näidanud, et lausetest aru saamine toimub kõige paremini (täpsemini, kiiremini) siis, kui edastatava sõnumi semantilise sisuga sobib kokku hääletoon e prosoodilise väljenduskanali informatsioon (vt ülevaadet Pell jt 2011). Uurijad ei ole päris ühte meelt selles osas, kumb informatsioon on ülimuslik. Ühest küljest on leitud, et inimhäälele prosoodiliste vihjete põhjal emotsiooni omistamine on protsess, mis toimub tahtmatult ja kiiresti (Pell jt 2011). Juhtumil, kui semantiline sisu on emotsionaalse tooni suhtes kas neutraalne või mitmeti tõlgendatav, on suurem roll täita auditiivsel kanalil. Näiteks oleneb lause Riina 
sai palgakõrgendust interpretatsioon kõneleja hääletoonist. Üldjuhul saavad kuulajad üsna hästi aru, kas kõneleja on sündmuse üle siiralt rõõmus või kõlab tema hääles kadeduse noot (Paulman jt 2011). Teisalt on leitud ka, et reaalajas teksti kuulates võib semantilise kanali informatsioon mõnel juhul osutuda prosoodiast olulisemaks (Pell jt 2011). Näiteks on lastel ja teise keele õppijatel raske aru saada lausungi iroonilisest toonist. Seetõttu tõlgendavad nad öeldut otsesõnu, lähtudes semantilise tasandi infost. Kolmandaks on kirjanduses väljendatud seisukohta, et kuna vastuvõtja töötleb signaali niikuinii omal viisil, milles on palju objektiivsest signaalist sõltumatut, ei määra emotsiooni atributsiooni lausungile mitte sõnumi sisu ega selle objektiivselt mõõdetavad prosoodilised parameetrid, vaid situatiivne kontekst. Näiteks võib isegi täpselt samal viisil intoneeritud lausung ei või olla väljendada sõltuvalt olukorrast nii suurt imestust, üllatust, aga olla öeldud ka suure hirmu või kohkumisega (Reilley, Seibert 2003).

On leitud, et kuigi neuroloogilisel tasandil võib tegemist olla osaliselt iseseisvate protsessidega, mis leiavad aset eri ajupiirkondades, toimub semantilise sisu ja akustilise väljenduse analüüs samaaegselt ning need protsessid on omavahel seotud. Emotsionaalse prosoodia toimimise mehhanismina on välja toodud selgitus, mille kohaselt on prosoodia roll aktiveerida või võimendada emotsioonidega seostuvat ainest mälus, mis omakorda soodustab sõnaliste stiimulite kognitiivset töötlust (Paulmann jt 2011). Siinkirjutaja julgeb teha oletuse, et prosoodia annab (vastuvõttu võimendades) emotsiooni edasi kiiresti ja suhteliselt robustselt, sellal kui semantiline kanal lubab teha täpsemaid eristusi ning järeldusi.

Kokkuvõttes kujutab emotsionaalse kõne kuulamine endast arvatavasti mitmeastmelist protsessi. Esimene aste on emotsioonivihjete (iseloomulikud prosoodilised vihjemustrid, valents ja aktivatsioon) kokkurehkendamine, teise astmena võib järgneda lause konnotatsiooni seostamine mälus leiduva emotsionaalse informatsiooniga ning kolmanda astmena lause lõplik interpreteerimine. Kuigi loomult mitmeastmeline, on suulise kõne emotsionaalsusest arusaamine normaalse täiskasvanud inimese puhul millisekundite küsimus (Paulmann jt 2011).

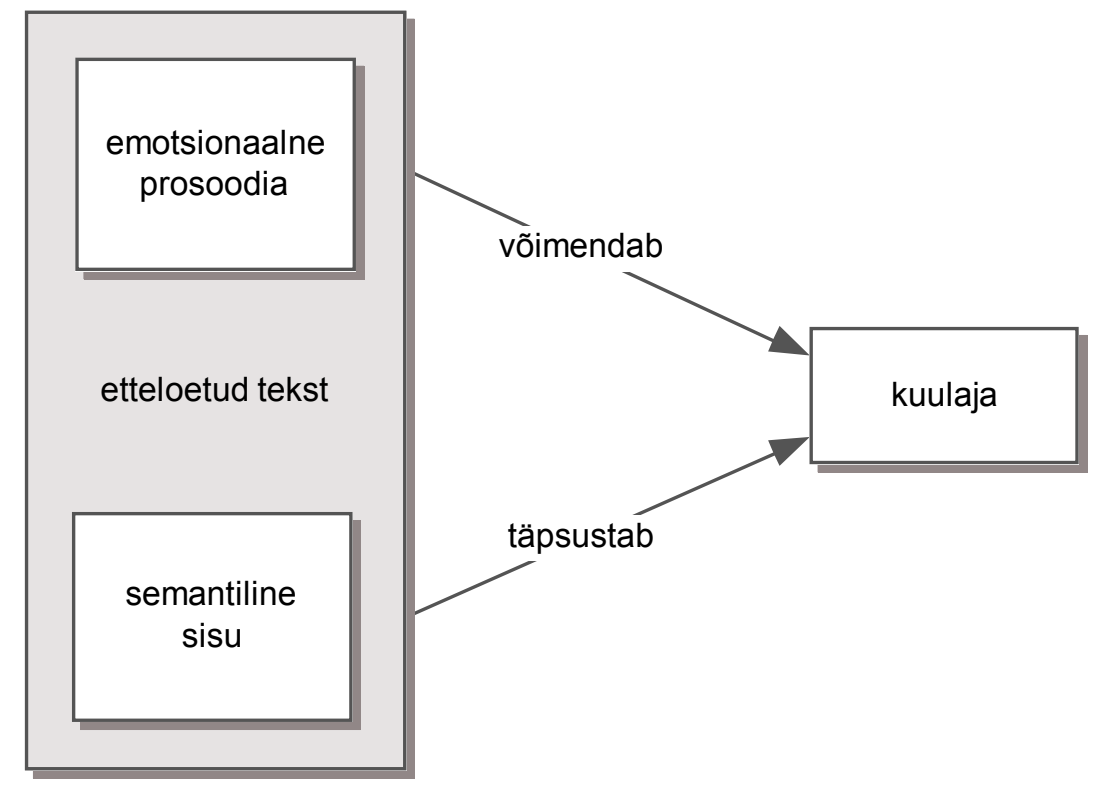

Joonis 1. Emotsionaalse kaasaelamisega etteloetud teksti vastuvõtt 
Skemaatiliselt esitab teksti ettelugemisel esinevat olukorda joonis 1, milles hall kast kujutab kuulajale esitatavat kaheplaanilist helisõnumit. Osa sellest moodustab tekst, st sõnumi semantiline sisu, ja osa ettelugeja kõnetoon, mis järgib etteloetava tekstiga kaasnevaid emotsionaalseid tõuse ja langusi. On oluline, et prosoodiline väljendus oleks kooskõlas, või vähemasti mitte vastuolus semantilise sisuga, kuna on üldine seaduspärasus, et vastuolulise informatsiooniga toimetulek nõuab kognitiivset lisapingutust, mis väljendub töötlusaja pikenemises (vt Kahneman 2011). Semantilise sisuga kooskõlas olev prosoodiline väljendus seevastu hõlbustab kuuldava teksti vastuvõttu reaalajas, kui kõnet ei ole võimalik tagasi kerida ega kahtluse korral uuesti kuulata.

\section{Tekstisisesed perspektiivid: peategelane ja autor}

Kuidas toimub teksti peategelase e protagonisti emotsioonide mõistmine? Psühholoogia valdkonnas tehtud katsed on näidanud, et lugejad konstrueerivad oma meeles (kuigi mitte teadlikult) mingisuguse ettekujutuse teksti keskse tegelase emotsionaalsest seisundist ning on võimelised jälgima selle muutumist tegevuse arenedes. Seejuures on leitud, et lugejad tulevad toime representatsioonide varal, mis on abstraktsemad konkreetsetest emotsiooninimetustest (ei eristata nt kahetsust, piinlikkust ja häbi), kuid on samas spetsiifilisemad valentsimäärangutest nagu positiiune vs. negatiiune (Gygax jt 2003, de Vega jt 1996). Opereeritakse mingisuguste vahepealsel spetsiifilisuse astmel olevate klastritaoliste või grupiviisiliste representatsioonidega, mille olemuse kohta ei ole aga veel täit selgust (Molinari jt 2009, Gygax jt 2003). Järeldusi protagonisti emotsioonide kohta tehakse jooksvalt ning automaatselt ning seda isegi juhul, kui tekstis otsesõnu ühelegi emotsioonile viidatud ei ole. See on võimalik, kuna lugejad mõistavad tekstis kirjeldatud sündmusi - seal esinevate isikute tegusid, eesmärke ja suhteid teiste tegelastega (Molinari jt 2009, Gernsbacher, Robertson 1992, viidatud de Vega jt 1996 kaudu).

Kui inimene loeb teksti, siis ta ei analüüsi igas üksikus lauses peituda võivat emotsiooni, vaid talitab ökonoomsemalt: mingi ettekujutus teksti(lõigu) peategelase emotsioonist konstrueeritakse teksti algusosas ja hiljem tulevatest tekstiosadest korjatakse üles vihjed, mis esialgset ettekujutust kas kinnitavad või kummutavad. Kui sündmuste edenedes ilmneb uusi asjaolusid, tehakse peategelase emotsionaalses representatsioonis muudatus. Peategelase emotsioonide viimast, "kehtivat" representatsiooni hoitakse aktiivsena alal ka neutraalsete lausete vältel, mida võib emotsionaalset infot sisaldavate vahel olla kuni neli-viis. Kui edasises tekstiosas lisandub informatsiooni, mis on emotsionaalses mõttes "ebaloogiline", st ei klapi mudeliga, mille lugeja on oma peas peategelase seisundist jooksvalt konstrueerinud, siis selliste vastuoludega toimetulek nõuab lugejalt lisapingutust, mis väljendub töötlusaja pikenemises (de Vega jt 1996). Üldiselt on lugejatel ootus teksti peategelase e protagonisti emotsioonide loogilise arengu suhtes. Viimast on peetud koguni "liimiks", mis narratiivi erinevaid osi sidusaks ja loogiliseks tervikuks seob (de Vega jt 1996 ja seal viidatud kirjandus).

Kuidas avaldub autori emotsionaalne suhtumine? Selle põhjal, kas ja kuidas teksti autor oma peategelase tegemisi kas vähem või rohkem emotsionaalselt ning kaasaelamisega või distantseeritult kirjeldab, saab lugeja midagi järeldada teksti autori hoiaku ja emotsioonide või siis nende puudumise kohta. Kirjandusteaduses 
on alternatiivseid võimalusi käsitletud eri fokaliseerimistüüpidena, millega kaasneb kas subjektiivne (kaasaelav, ingl involved) või objektiivne (mittekaasaelav, uninvolved) emotsionaalne vaatepunkt (Rimmon-Kenan 2002: 82, viidatud Bednarek 2008: 185 vahendusel). Teiseks on teksti-ja žanrianalüüsis tegeldud hoiaku (stance) käsitlemisega, mis kätkeb endas autori isiklikke tundeid ja hinnanguid. Eristatakse episteemilist hoiakut (kahtlus, kindlus) ja suhtumishoiakut (positiivne vs. negatiivne suhtumine, tunded) (Conrad, Biber 2000: 57, viidatud Bednarek 2008: 16 järgi).

Autori emotsionaalne kohalolek $v$ s. distantseeritus on üks olulisi aspekte, mille poolest tekstižanrid erinevad üksteisest. Ilukirjanduse autorilt eeldatakse, et ta loob sellised karakterid, kelle tegemiste ja tunnetega nad tunnevad empaatilist sidet (Keen 2006: 221). Ajakirjanduses on žanriti ja väljaandeti erinevusi. Liigne emotsionaalne kaasaelamine võib ajakirjanduses olla isegi taunitav. Näiteks esitas riigikogusaadik Igor Gräzin käesoleva artikli kirjutamise ajal protesti Eesti Rahvusringhäälingu suhtes, kuna leidis, et keelekasutus riigitelevisioonis ei ole piisavalt neutraalne. ${ }^{2}$ Päevik, blogipostitus ja isiklik kiri kujutavad seevastu žanreid, mille sees autoril on vabadus väljendada ja/või üsnagi üksikasjalikult kirjeldada iseenda tundeid. Tal on ka vabadus rääkida täie kaasaelamisega kolmandatest isikutest iroonilise alatooniga või naljatledes, neid andunult ülistades, hukka mõistes, halvustades jne.

Ka autori emotsioonide puhul ei saa üldjuhul eeldada, et need oleks väljendatud ja määratletavad kategoriaalselt ja otsesõnu (rõõm, viha, hirm, üllatus, vastikus, kadedus jne). Pigem kujuneb lugejal teksti autori emotsionaalsest seisundist samuti mingit laadi abstraktsem representatsioon (nt psühholoogilise distantsi ja/või hinnangu näol).

Juhtumil, kui tekst on kirjutatud mina-vormis, st esimese isiku positsioonilt, on autor ja protagonist üks ja seesama isik. Kuivõrd taolises intiimsemas žanris varustatakse lugejat informatsiooniga autor-protagonisti plaanide, tegevuse, edu ja ebaedu ning suhete-suhtlemise kohta teiste inimestega, on lugejal märksa rohkem pidepunkte, mille najal konstrueerida endale ettekujutus autor-protagonisti emotsioonidest, kui neid ka otsesõnu ei mainita.

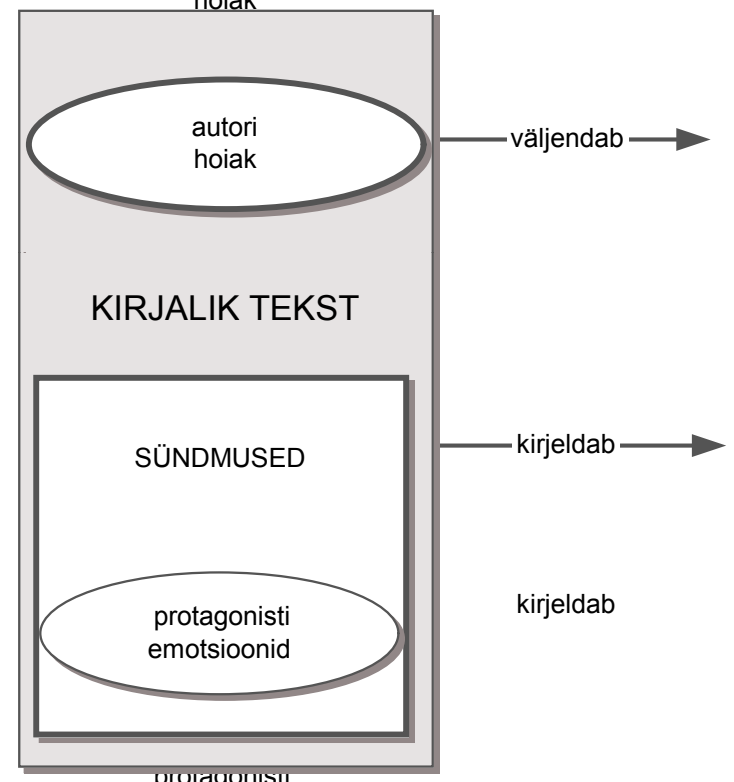

Joonis 2. Autori ja protagonisti emotsioonide vahendamine tekstiga

2 http://www.epl.ee/news/eesti/igor-grazin-peab-err-i-uudiste-tooni-lubamatuks.d?id=65327458 (22.9.2013). 
Skemaatiliselt esitavad tekstis endas sisalduda võivaid emotsioone ja/või hoiakuid joonisel 2 leiduvad ovaalid. Kui on tegemist minajutustusega, langevad teksti kirjeldav ning väljenduslik plaan ning kaks võimalikku eri perspektiivi kokku üheks. Objektiivsust taotlevates žanrides seevastu on emotsionaalne distants autori ja peategelase vahel suurem või puudub autori hoiakute väljendusplaan sootuks ning piirdutakse kirjeldusega.

\section{Lugeja perspektiiv}

Selle kohta, kuidas inimesed tekstis leiduvat emotsionaalset informatsiooni kasutavad, on samuti mitmeid eri teooriaid. Eespool oli juttu teksti peategelase emotsioonidest dünaamilise mudeli konstrueerimisest (de Vega jt 1996). On leitud aga, et selle kõrval, et lugeja n-ö kognitiivne aparaat protagonisti ja autori emotsioonidest mingil tasemel ettekujutuse loob, elab ta ka ise midagi emotsionaalsel tasandil läbi või kaasa.

Lugeja emotsioonide vastu on huvi tuntud nii erinevates humanitaarse suunitlusega teadusharudes (nt lingvistiline pragmaatika, kirjandusteadus, filosoofia, sotsiaalpsühholoogia, kriitiline tekstianalüüs) kui ka inimese ja masina suhtlusele keskenduvatel aladel, nt afektirehkenduses (ingl affective computing) või ka turunduses ja reklaaminduses. Emotsioonide esilekutsumise kaudu on inimesed teatavasti hõlpsasti mõjutatavad ja ka manipuleeritavad. See oli teada juba antiikses retoorikaõpetuses (Aristotelese “Retoorika”, viidatud Caffi, Janney 1994: 334 vahendusel).

Filosoofias ja kirjandusteaduses on arutletud selle üle, kas teksti lugemisel tekkivad tunded on tõelised emotsioonid või mingisugused libaemotsioonid (ingl quasi emotions, make-believe emotions, vt Walton 1990: 195-204, viidatud Sklar 2009 vahendusel). Emotsionaalses reageerimises just eriti ilukirjandustekstile on nähtud filosoofilises mõttes paradoksi, kuna emotsiooni esilekutsujana esineb nähtus, mille kohta kogejatel on kindel teadmine, et seda - nt romaani peategelast ja tema kannatusi - pole üldse reaalsuses olemaski (Sutrop 1999). Seepärast on oletatud, et inimesed reageerivad lugedes mitte reaalse elu nähtustele, vaid teatud sorti kujutlustele või representatsioonidele. Välja on pakutud nn simulatsiooniteooria, mis tähendab kirjanduses esitatavate narratiivide n-ö mahamängimist meie sisemises multimodaalsete representatsioonide teatris, koos vastavate emotsionaalsete reaktsioonidega (nt Currie 1998). On ka väidetud, et lugejad süüvivad (immerse) teksti sellisel määral, et seisund on võrreldav unenägude ajal kogetavaga, viimast seisukohta näivad toetavat uurimused nn tekstiga kaasa-minemise (transportation) fenomenist (Gerrig 1993, viidatud Sklar 2009 vahendusel). Sotsiaal-psühholoogias läbi viidud uurimustes on leitud aga, et tekstist indutseeritud emotsioonid ei pruugi kvalitatiivselt siiski erineda vahetult elusituatsioonides kogetavatest emotsioonidest, võtmeteguriks on, kuivõrd lähedaselt seotuna tunneb lugeja end tekstis kirjeldatud tegelaste, sündmuste ja asjaoludega (Myyry, Helkama 2007: 251, viidatud Sklar 2009 vahendusel).

Arvatakse ka, et ilukirjanduse lugemisel tekkiva emotsionaalse kaasaelamise võlgneme empaatiale ${ }^{3}$ kui võimele mõista ja mingil määral jagada teiste inimeste tundeid. Empaatia aluseks on samastumisvõime e oskus tajuda maailma teise olendi 
perspektiivist (de Waal 2009). Nagu paljude evolutsiooniliselt omandatud asjadega, ei ole meil sisuliselt valikut, kas olla empaatiline või mitte ja seetõttu rakendub see võime ka siis, kui loeme ilukirjandust, vaatame filmi või loome ise erksaid kujutluspilte, mille keskmes on teiste inimeste edu või ebaedu. Empaatia määr varieerub mingil määral isikuti ja on keskeltläbi naistele omasem kui meestele (vt nt Baron-Cohen 2003). Empaatilisi inimesi on peetud "paremateks lugejateks" (Keen 2006) ja arvatavasti on seepärast just naistele suunatud nii suur hulk spetsiifilist kirjandust kui ka ajakirjandust (nn "naistekad").

Teisest küljest pole saladus, et kirjanikud teevad lugejate emotsionaalseks kaasahaaramiseks ka teadlikke pingutusi. Kirjandusteaduses on kirjeldatud järgnevaid empaatia esilekutsumise tehnikaid: jutustamine esimese isiku vaatepunktist, karakteriloomise vahendid nagu tegelasele isikupärase nime andmine, välimuse kirjeldus, iseloomuomadustele osutamine, kirjeldatavate tegevuste laad, liikumine, kõnemaneer jne. Arvatakse, et vahetu kohaloleku ja situatsiooniga ühendatuse tunnet suurendab oleviku aja kasutamine mineviku asemel. (Keen 2006: 215-216)

Ka ajakirjanduse uurimise kontekstis on tegeldud lugeja emotsioonide kujunemisega. Ungerer (1997) on osutanud, et artiklis sündmuse tasandil kirjeldatud (protagonisti) emotsioonid ei pruugi kokku langeda nendega, mida on kavas äratada lugejates. Ajakirjaniku või toimetuse poolt kavatsetud mõjutusemotsioon võib olla siiski kirjeldatuga mingisuguses järelduslikus seoses: nt kirjeldades mõrtsuka rõõmu, äratatakse inimestes viha, kirjeldades mõrtsuka pisaraid, omistatakse talle kahetsus ja tekitatakse lugejates kaastunnet. Ajakirjanduse lugejas reaalselt tekkivaid emotsioone on raske täpselt määratleda sellepärast, et lugeja emotsioon tekib emotsionaalsete järelduste tulemina, millega ta reageerib tekstis leiduvatele päästikutele/vihjetele (trigger/cue) (Ungerer 1997: 309). Need vihjed või päästikud panustavad kas ühele või mitmele nn emotsionaalse ruumi dimensioonile, milleks on pakutud psühholoogias ammu tuntud semantilise ruumi kolme dimensiooni (Ungerer 1997, Caffi, Janney 1994, dimensioonid pärit Osgood jt 1957). Dimensioonid on: a) hinnang (meeldiv vs. ebameeldiv); b) aktiivsus (erutatus, intensiivsus); c) võim, kontroll (ingl potency). Hinnang ja intensiivsus on tekstis kergemini ära tuntavad, kuid võim, kontroll raskemini. Selle n-ö potentsidimensiooni teenistuses on need elemendid tekstis, mis viitavad lähedusele, spetsiifilisusele, evidentsiaalsusele, tahtelisusele (Caffi, Janney 1994). Toda raskestitabatavat dimensiooni on lingvistikas nimetatud ka pühendumiseks ja seotuseks (commitment, involvement) (Ungerer 1997: 312).

Ka lugejas tekkiv emotsioon võib olla rohkem või vähem spetsiifiline. Näiteks, kui esitatakse fakte võimurite valelikkusest, siis reaktsioonina tekib lugejates tõenäoliselt nördimus ja viha. Vähem spetsiifiline on emotsionaalne kaasaelamine, kui tekstiga hinnanguid ei kaasne, või kui see sisaldab vastuolulisi hinnanguid. Näiteks, kui kirjeldatakse sportlase ponnistusi teel olümpiale. Lugejad elavad kaasa edule ja tagasilöökidele, kuid raske oleks väita, et nad ühe lause juures tunnevad täiemahulist rõõmuemotsiooni ja järgmise lause juures kurbust - seda eriti tingimustes, kui lõplik otsus sportlase saatuse kohta polegi veel tehtud. Lisaks hinnangule mõjutab lugeja emotsiooni tugevust ja selgepiirilisust ka see, kas tekstis on juttu lähedastest või kaugetest, elulistest või abstraktsetest, võimuga seotud või mitteseotud sündmustest jpm. Emotsionaalne järeldamine on kahtlemata mitmetasandiline ja kompleksne protsess, mille mehhanismid vajavad edasist uurimist. 


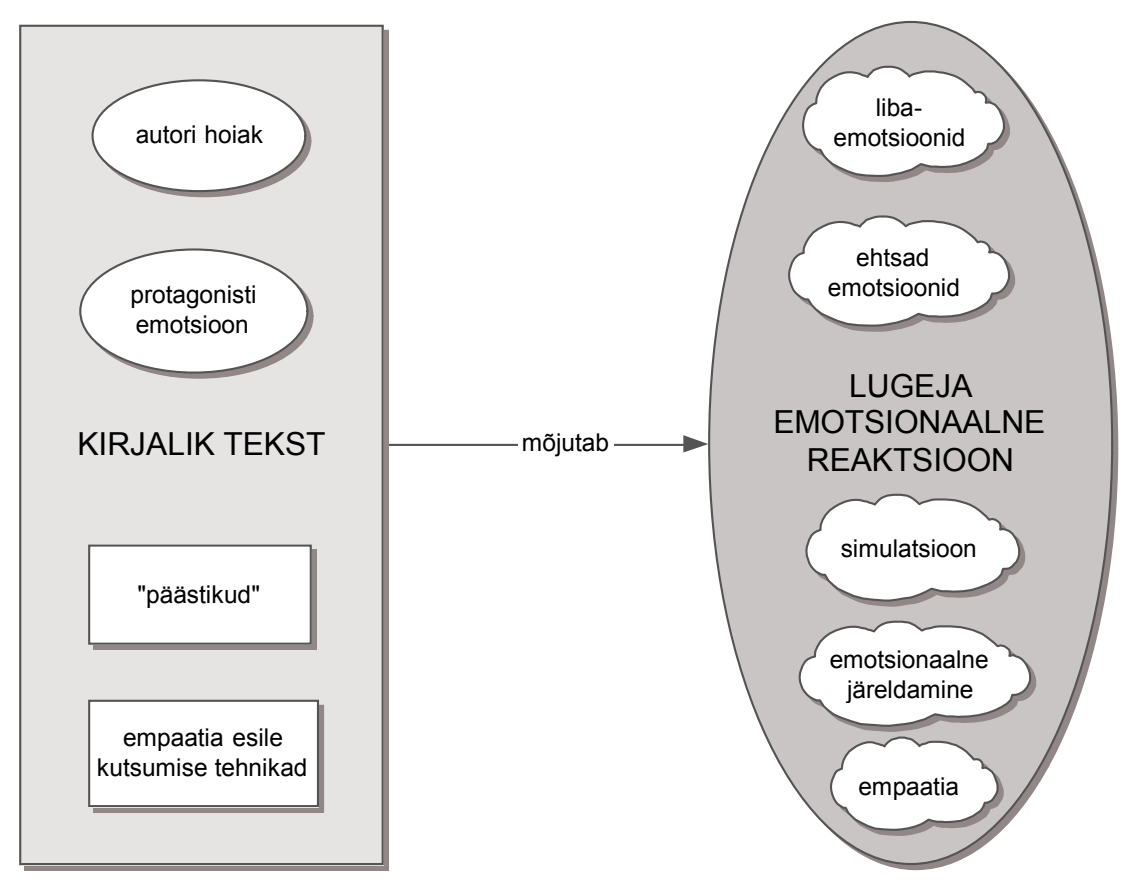

Joonis 3. Lugeja emotsionaalse reaktsiooni kujunemine

Kokkuvõtlikult võib öelda, et lugeja võimes tekstile emotsionaalselt reageerida ei kahtle keegi, küll on aga erinevaid teooriaid selle kohta, mida need lugeja emotsioonid endast kujutavad ja kuidas tekivad. Skemaatiliselt esitab olukorda joonis 3. Joonise vasakut poolt, mis kujutab teksti, on võrreldes joonisega 2 lihtsustatud ja lisatud tekstis sisalduda võivad lugeja emotsioone esile kutsuvad elemendid. Pilvekujulised väljad, mis on paigutatud lugeja emotsionaalset reaktsiooni kujutava ovaali sisse, esitavad oletusi, mida on kirjanduses lugeja emotsionaalse reaktsiooni olemuse ja selle kujunemise mehhanismide kohta tehtud.

\section{Ettelugeja perspektiiv}

Mida teeb tekstiga inimesest ettelugeja? Teksti ettelugemine nii, et see mõjuks kuulajale loomulikuna, ei ole ka inimese jaoks ülesanne, millega igaüks hõlpsasti ja ilma eriettevalmistuseta hakkama saaks. Kuigi nn ilmekas lugemine kuulub meil kohustusliku alghariduse hulka, ${ }^{4}$ kalduvad tavainimesedki teksti esitama mehhaaniliselt ja kaasaelamiseta. Näiteks eesti keele emotsionaalse kõne korpuse ${ }^{5}$ koostamise käigus kogeti, et soovitava ilmekuse kohta juhiseid saamata kaldusid mitteprofessionaalidest ettelugejad teksti esitama tuimalt. Rahuldav esituse loomulikkus saavutati instruktsiooniga "tuua esile teksti meeleolu". On mõistetav, et ettelugejad soovisid ülesandega toimetulekuks tekstiga eelnevalt tutvuda ning ettelugemist koguni harjutada (Altrov 2007: 24).

Nagu eelnevas osas välja toodud, on ettelugejal tekstiga tutvumise järel võimalik esiletoomiseks valida kahest erinevast allikast tuleneva emotsionaalse värvingu vahel: tekstis tegutseva tegelaskuju (protagonisti) emotsioonide või siis teksti autori emotsionaalse hoiaku vahel (vt joonis 2). On ka kolmas võimalus: ettelugeja ei püüa

4 Vt http://www.teatoimeta.ee/Lea_Nurkse_1904-1960_288.htm (13.9.2013).

5 Eesti emotsionaalse kõne korpus http://peeter.eki.ee:5000/ (13.9.2013). 
mitte niivõrd empaatiliselt sisse elada teksti autori või tekstis kujutatud inimeste rolli, vaid laseb hääletoonis kõlada iseenda emotsioonidel (joonis 3). Just viimane oligi nähtavasti eesti keele emotsionaalse kõne korpuse loojate eesmärgiks, kui otsustati kasutada mitte näideldud kõnet vaid n-ö tavainimese poolt sisseloetud teksti. Eeldatakse, et ettelugejal kujuneb konteksti najal mingi oma hinnang tekstis kujutatud sündmustest, ja et sellele hinnangule tugineva emotsiooni kannab ta etteloetavale tekstile häälega üle (Altrov, Pajupuu 2012: 50). Ettelugejatele antud juhend "tuua esile teksti meeleolu" tähendab seega eelkõige juhendit tuua välja ettelugejas endas tekkinud emotsionaalne seisund: kui tekst teda ärritab, kandub ärritus etteloetavale tekstile, kui tekst masendab, siis loeb ta teksti ette rusutud hääletoonil jne. Seega on nn "teksti meelolu" ja selle tulemusena etteloetavatele tekstilõikudele (ja lausetele) lugeja poolt rakendatav emotsioon loomult projektiivset laadi, mis võib, aga ei pruugi olla vastavuses teksti protagonisti ja/või autori emotsiooniga.

Selle tõestuseks, et "teksti peal" paiknev projektiivne ettelugeja emotsioon ja tekstis sõnadega väljendatud (kas autori või protagonisti) emotsioon ei ole üks ja seesama, on ka tulemused, mis on saadud eesti keele emotsioonikorpuse etteloetud lausete emotsioonide määramisel (vt nt Altrov, Pajupuu 2012). Kuivõrd eraldi katses ja erinevatel katseisikutel lasti määrata samade lausete emotsioon vastavalt kas ainult kirjalikul kujul (lugemistest) või etteloetuna (kuulamistest), siis tuli välja, et keskmiselt 45\% lausetest on ettelugeja lugenud mingi muu emotsiooniga, kui see, mis äratuntavalt esineb kirjalikus tekstilauses (vt tabel 1). Osutub ka, et ettelugeja kaldub teksti esitama pigem neutraalsemalt ja kurvemalt, kui lausete sisu eeldaks tekstile neutraalsuse ja kurbuse n-ö "peale lugemine" on protsentuaalselt kõrgem. Teksti lugemist rõõmsamana, kui sisu eeldaks, tuleb teiste tonaalsustega võrreldes ette vähem, kuid siiski ligi 30\%-l lausetest. Järelikult on ettelugeja projektiivsed emotsioonid (nii nagu nad testkuulajate hinnangute põhjal identifitseeriti) suhteliselt lõdvalt seotud tekstilausete sisuplaanis väljendatud emotsioonidega (nii nagu need ilma helita lugemiskatsetes identifitseeriti).

Ennatlik oleks ettelugeja projektiivsete emotsioonide ja tekstis sisuplaanis identifitseeritavate emotsioonide erinevust käsitleda lugeja vähese kompetentsusena, pigem seletab nähtust asjaolu, et lugeja oli orienteeritud terviktekstile (lõigule) ja mitte üksikute lausete esitamisele, nagu tulemusi kuulamis- ja lugemistestides hinnata lasti. Teine põhjus tõlgenduste erinevuseks tuleneb ilmselt sellest, et nii tekstis kui hääletoonis väljenduvad emotsioonid varieeruvad oma spetsiifilisuse (s.o kategoriaalse määratletavuse) astmelt ning see loob ruumi vastuste hajuvusele.

Tabel 1. Lausete distributsioon emotsioonimäärangute vahel võrrelduna lugemiskatse ja kuulamiskatse lõikes

\begin{tabular}{|l|c|c|c|c|}
\hline Emotsioon & Lauseid & “Sisu mõjutab" & “Sisu ei mõjuta" & Projektiivsete omistuste \% \\
\hline rõõm & 232 & 163 & 69 & 29.74 \\
\hline viha & 277 & 177 & 100 & 36.10 \\
\hline kurbus & 191 & 88 & 103 & 53.93 \\
\hline neutraalne & 208 & 87 & 121 & 58.17 \\
\hline
\end{tabular}

Märkus. Andmed pärinevad Altrovi ja Pajupuu (2012) artiklist, hallid alad on autori poolt juurde arvutatud. 
Nagu käesolevast jaotisest välja tuli, võib tavainimesest ettelugeja lisada ja keskmiselt iga teise lause puhul lisaski kirjutatud tekstile omalt poolt teistsuguse emotsionaalse interpretatsiooni, kui oli antud lause sisu tasandil. Tulemuseks on see, et etteloetud teksti kuulaja saab rohkem ja osaliselt teistsugust informatsiooni, kui seda oli kirjalikuna esitatud lausetes, kuna ettelugeja on teksti "rikastanud" enda emotsioonidega.

Kokkuvõtlikult kujutab olukorda joonis 4. Joonise vasakul poolel kujutatud sisu emotsionaalsed aspektid on samad, millest eelpool on olnud juttu (joonis 3): autori hoiak ja protagonisti võimalik emotsioon, tekstis kasutatud empaatia tekitamise tehnikad, "päästikud". Teksti sisu emotsionaalsed aspektid kanduvad üle etteloetud lausesse, ettelugeja poolt väljendatav projektiivne emotsioon võib kas olla teksti sisust tuleneva emotsiooniga kooskõlas või mitte.

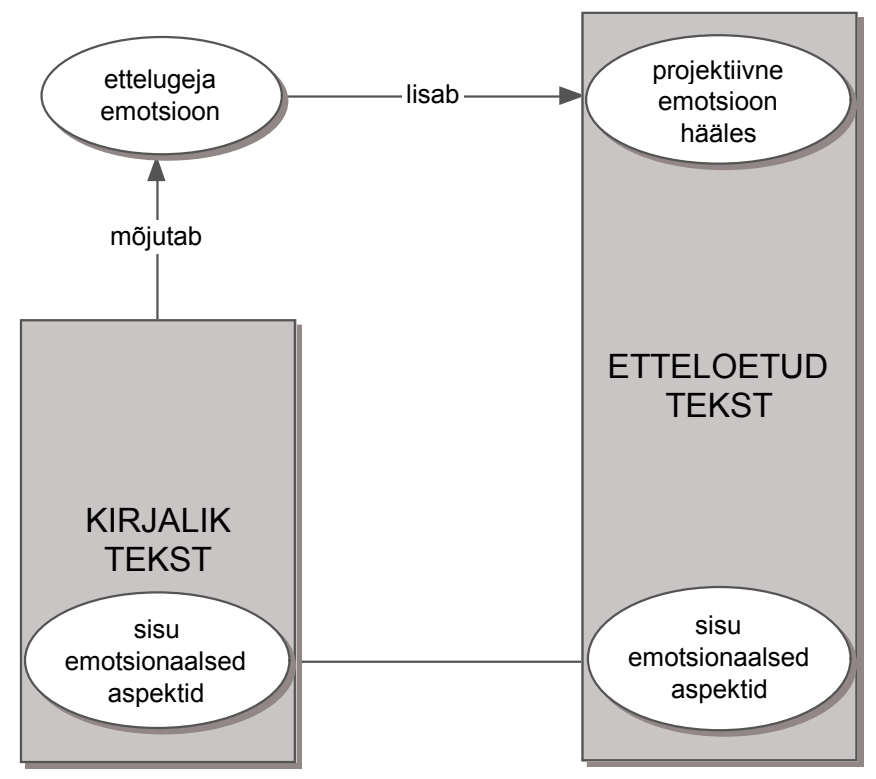

Joonis 4. Ettelugeja emotsiooni lisandumine tekstile

\section{Arvuti perspektiiv}

Kuidas otsustab arvuti (kõnesüntesaator), millise emotsionaalse registriga tuleks loetavat teksti esitada? Eelnevast inimlike perspektiivide ülevaatest nähtus, et teksti esitamisel relevantsed emotsioonid võivad kuuluda erinevatele isikutele (protagonist, autor, ettelugeja) ning varieeruda spetsiifilisuse astmelt. Kelle perspektiivi peaks süntesaator esmajoones võtma ja millisel täpsusastmel emotsioone väljendama?

Nn afektirehkenduse (ingl affective computing) tehnoloogiavaldkonnas ning selle vajadustest tõukuva uurimisparadigma raames püütakse leida võimalikult hõlpsasti teostatavaid lahendusi emotsionaalsuse realiseerimiseks arvutil. Kuivõrd tegeldakse rakendustega ning mitte eeskätt teooriate ja avastustega inimeste kohta, on kasutusele võetud erinevate isikute perspektiive tasalülitav termin "teksti emotsionaalsus”, mis käsitleb emotsioone justkui teksti ja selle osade (nt lõikude, lausete) omadustena (vt nt Pajupuu jt 2012 ja seal esitatud viited). Käsitlus, mis omistab emotsioone tekstile (lõikudele, lausetele) ja mitte eeskätt isikuile, saab olla üksnes 
metafoorne. ${ }^{6}$ Terminoloogiline piltlikkus ei sega loomulikult tekstis sisalduvate võtmesõnade valentside põhjal “teksti emotsiooni” välja arvutamast - ka eesti keele jaoks on juba loodud emotsioonidetektor, ${ }^{7}$ mis kalkuleerib tekstilõikude valentsi selles sisalduvate emotsionaalset värvingut omavate sõnade (nn "võtmesõnade") väärtuste (positiivne vs. negatiivne) summana. Taolise tekstuaalse üldafekti kalkuleerimise juhul oleks siinkirjutaja arvates psühholoogilise realistlikkuse huvides siiski korrektsem rääkida mitte teksti või lõigu emotsioonist ja selle tuvastamisest, vaid emotsiooni atributsioonist tekstile (lõigule, lausele). See, kas tehnoloogilisest vajadusest ellu kutsutud lähenemised peaksid üldse olema ka psühholoogiliselt realistlikud või mitte, on muidugi omaette arutlusteema.

Kui süntesaator hakkaks teksti ette lugedes juhinduma taolisest tekstile omistatud üldafektist, siis kelle emotsioone ta õigupoolest jäljendaks? Osutub, et kui kirjanduses räägitakse "teksti emotsionaalsusest", siis vaikimisi toimib siiski selle nähtuse samastamine tekstivälise isiku - lugeja - reageeringuga (vt joonis 3). Seda käsitatakse teatud mõttes ülimuslikuna võrreldes teksti autori või tekstis esinevate tegelaste emotsioonidega. Pajupuu ja kolleegid (2012: 184) ei jäta selles suhtes mingit kahtlust: "[lugejahinnang] on kõige usaldusväärsem ehk õige, sest just lugeja annab tekstile tähenduse". Paraku, nagu tuli välja ettelugeja perspektiivi käsitlusest, oli ühe üksiku lugeja poolt tekstilausetele projitseeritud emotsioon üksnes lõdvalt seotud emotsioonidega, mida samade stiimulite puhul "tundsid ära" teised lugejad, kes osalesid lugemiskatses. Niisamuti olid ka lugemistestides osalenute endi hinnangud keskeltläbi üsna hajuvad (vt Vainik 2010).

Kirjanduses on seatud erinevaid konsensusnõudeid, kuid emotsioonide nelikotsustuste puhul on juba määrangute 50\%-st üksmeelt peetud piisavaks (Vogt jt 2008). Oletatavasti peaks süntesaator teksti analüüsima ja ette lugema nii, nagu teeks seda lugejate 51\%-line enamik. Seega on tekstist võtmesõnade põhjal kokku rehkendatava üldafekti e "teksti emotsiooni” näol tegemist hüpoteetilise keskmise lugeja potentsiaalse emotsionaalse reageeringuga.

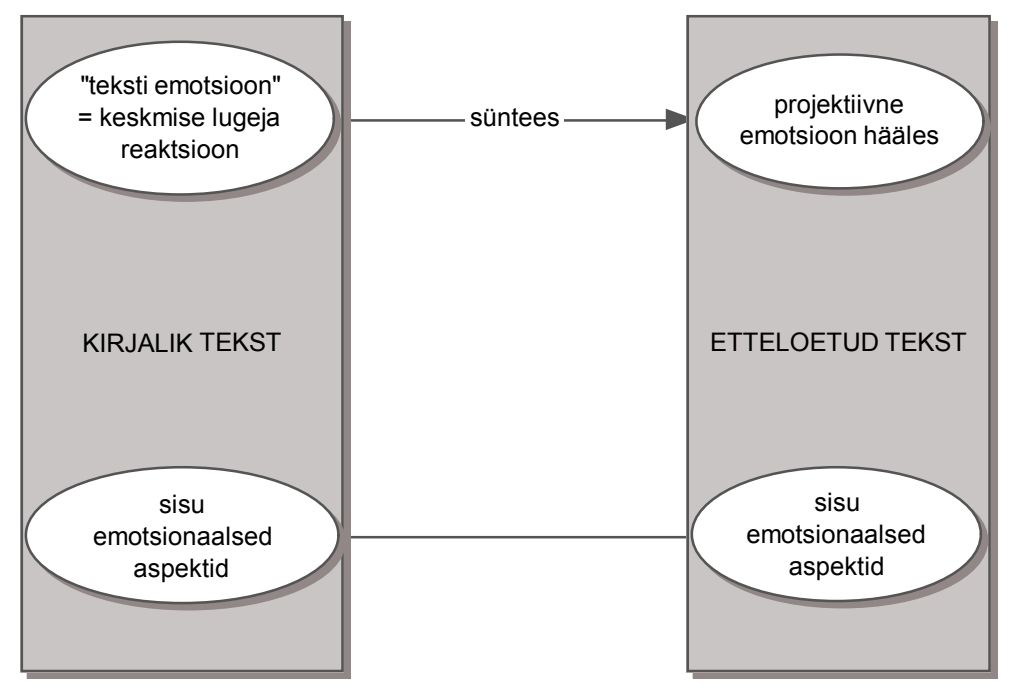

Joonis 5. Emotsionaalse prosoodia sünteesimine

6 Niiviisi mõtlema ja emotsioone elututele asjadele omistama suunab meid tavakeel. Näiteks omadussõna kurb kasutatakse nii tähenduses 'alanenud meelolu', nt kurb tüdruk, kui ka 'alanenud meelolu põhjustav', nt kurb film. Me saame siiski aru, et tüdruk ja film on kurvad hoopis iseviiisi: tüdrukul on meeleolu alanenud, kuid filmi kohta seda väita ei saa.

7 http://peeter.eki.ee:5000/valence (22.9.2013). 
Üldistatult võtab afektirehkenduses omaks võetud asjade käsituse kokku joonis 5 . Nn teksti emotsioon e keskmise lugeja oletatav reaktsioon tuleb sünteesida kui projektiivne emotsioon, mida väljendatakse häälega "teksti peal”. Kuna teksti sisu jääb samaks, siis paratamatult kanduvad etteloetavasse üle ka selle emotsionaalsed aspektid (autori hoiak ja protagonisti võimalik emotsioon, tekstis kasutatud empaatia tekitamise tehnikad, "päästikud").

Kas teksti põhjal kalkuleeritav hüpoteetilise keskmise lugeja emotsionaalne reaktsioon tuleks määratleda kategoorianimetustena (nt hirm, rõõm, kurbus, viha) või iseloomustustena dimensioonidel (nt valents, aktivatsioon)? Afektirehkenduse raames on kritiseeritud tekstide emotsionaalsuse klassifitseerimist pelgalt valentsi alusel, kuivõrd selline jaotus ei ole vastavuses keeletehnoloogilistes rakendustes vajatava kategooriate süsteemiga (Karlgren jt 2012). Ka eesti keele puhul on emotsionaalse prosoodia süntees planeeritud kategoriaalse mudeli põhjal - st kavas on esialgu luua vihale, rõõmule, kurbusele ja neutraalsusele omased intonatsioonid (vt nt Tamuri 2013). Siiski kujutavad emotsioonikorpuse lausete testimisel rakendatud kategooriad teatud mõttes üldisema tasandi nähtusi, kui seda on kitsalt vastavate emotsiooninimetuste (rõõm, viha, kurbus) tähendused. Kategooriad on ekstensiooni abil määratletud emotsioonide tavanimetustest laiemalt: rõom sisaldab tänulikkust, õnnelikkust, meeldivust ja elevust; kurbus sisaldab üksindust, muret, lohutamatust ja lootusetust ning viha kibestumist, irooniat, tõrksust, põlgust, pahatahtlikkust, raevu. Sellised klastritaolised kategooriad sobivad kokku uurimistulemustega, mis osutavad, et inim-meel eelistabki emotsioonidest luua ning mõttes jälgida mitte täiesti spetsiifilisi kategoorianimesid ega ka pelgalt valentsihinnanguid vaid pigem mingil vahepealsel spetsiifilisuse astmel olevaid representatsioone (Gygax jt 2003, de Vega jt 1996, Molinari jt 2009).

Seega tundub praegu emotsioonidetektori poolt tekstile antav määratlus positiivne, negatiiune, neutraalne või vastuoluline jäävat lõppeesmärki silmas pidades alamääratletuks ja seda tuleks täiendada vähemasti mingit sorti üleminekumooduliga, mis muudaks dimensionaalse kirjelduse (nt määratluse negatiivne) kategoriaalseks (nt kurbus). Kuna kategoriaalsed määratlused on loomult detailsemad ja kitsamad, siis vajab taoline moodul võrreldes valentsimääranguga lisainformatsiooni.

\section{Tulevikuperspektiiv}

Kui kirjalikul kujul esinevale tekstile hakata emotsionaalsete rõhuasetustega prosoodiat sünteesima, siis peaks tegema esmalt valiku, millise isiku häälel ja emotsioonidel lasta kõlada. On võimalik valida, kas süntesaator peaks teksti ette lugema empaatiliselt - tuues välja teksti autori ja/või teksti keskse tegelase e protagonisti emotsioonid - või pigem nagu tavainimene, kes etteloetavale tekstile oma emotsionaalse tõlgenduse lisab. Praeguse seisuga on tehtud valik tavainimese jäljendamise kasuks (Mihkla jt 2012). Projektiivset laadi emotsionaalse prosoodia puhul võib kooskõla teksti autori või protagonisti emotsioonidega olemas olla, kuid võib ka puududa.

Näib, et emotsionaalseks kõnesünteesiks läheb vaja mingit laadi Emonculus't, virtuaalset olendit, kes tekstis esinevatele stiimulitele "keskmise lugeja" sarnaselt 
reageerib ning oma virtuaalsed emotsioonid tekstile üle kannab, viimast prosoodiliselt rikastades. Seetõttu on eriti oluline saada suuremat selgust selle kohta, kuidas kujunevad ning mida endast kujutavad teksti lugemisel tekkivad emotsioonid (vt jaotist "Lugeja perspektiiv"). Otstarbekaks võib osutuda ka virtuaalsele Emonculus'ele erinevate isiksusetüüpide modelleerimine. Näiteks võiks olla nii, et neurootiline Emonculus rakendab enam ärevat või masendunud hääletooni, samas kui ekstravertne kalduks rohkem ekspluateerima reibast ja joviaalset kõnemaneeri.

Emonculus'te loomine lahendaks ka probleemi, kuidas minna üle tekstilausele võtmesõnade põhjal kalkuleeritud dimensionaalsetest määrangutest spetsiifilisemate emotsioonide juurde. Olukorras, kus informatsiooni tekstis (lauses) napib (nt pole võimalik identifitseerida, kas negatiivsus peaks lugejat tegema pigem vihaseks või kurvaks) lähtub Emonculus enda sisseprogrammeeritud loomupärasest kalduvusest - neurootiline rakendab kahtluse korral rusutud ja ekstravertne ärritunud hääletooni. Sama teevad ka tavainimestest ettelugejad.

\section{Õppetunnid eri perspektiividest}

Artiklis refereeritud kirjandus, nende põhjal loodud skeemid ning arutelu aitasid lugejal loodetavasti aru saada, et tekstiga võivad olla seotud erinevad inimlikud vaatepunktid ja sellest tulenevalt on mingil määral ka erinevad lähenemised ning arusaamised emotsionaalsetest seisunditest. Ülevaatlikkuse mõttes võetakse järgnevas kokku olulisemad õppetunnid.

Kuulaja perspektiivile keskendumine õpetas, et sisuga kooskõlas oleva emotsionaalse prosoodia ülesanne on aktiveerida emotsionaalset ainest vastuvõtja mälus ning seega hõlbustada kuuldava teksti vastuvõttu reaalajas. Emotsionaalsel prosoodial on suurem roll nende lausete tõlgendamisel, mille sisu on kas vastuoluline või neutraalne.

Peategelase perspektiivi kohta selgus, et lugejad konstrueerivad tema emotsionaalsest seisundist oma peas dünaamilise mudeli, ning et lugejal on ootus tema emotsioonide loogiliseks arenemiseks, vastuoluline info nõuab töötlusel lisaaega.

Autori perspektiivi arvessevõtt juhatas mõistma, et ta võib kirjeldatava suhtes olla kas emotsionaalselt osavõtlik või distantseeritud. Kui tekst on mina-vormis, langevad autori ja peategelase perspektiiv kokku.

Teksti lugeja perspektiivile keskendumine tõi esile, et selles osas valitseb kirjanduses oletuste ja seletuste paljusus. Levinud seletus lugeja emotsioonidele on empaatiavõime, kuid selle kõrval on välja pakutud ka simulatsiooni ning teksti põhjal emotsionaalsete järelduste tegemist. Viimase kirjeldamisel on peetud otstarbekaks nn semantilise ruumi kolme dimensiooni: hinnangut, aktiivsust ja potentsi.

Ettelugeja perspektiivist vaadates osutus, et tavalugeja projitseerib etteloetavale tekstile enda emotsionaalse seisundi ega samastu ilmtingimata alati lause peategelase ja/või autori emotsiooniga: ligikaudu poolte lausete puhul väljendas ta oma hääles äratuntavalt mingisugust muud emotsiooni kui see, mis oli teksti põhjal lausele konsensuslikult teiste lugejate poolt omistatud.

Iga tekstiga seotud isiku emotsioonide puhul võis tõdeda, et need saavad olla väljendunud ja äratuntavad kas spetsiifilisena või mittespetsiifilisena. Kui 
konkreetsele emotsioonikategooriale otsesõnu tekstis viidatud ei ole (puuduvad emotsiooninimetused, vt nt Vainik 2002), siis saadakse hakkama mingit laadi abstraktsema, vahepealsel spetsiifilisuse astmel oleva representatsiooniga, mis on siiski komplekssem pelgast valentsimäärangust (positiivne vs. negatiivne).

Arvuti perspektiivi tundmaõppimine tõi esile, et rakenduslikust eesmärgist lähtudes saab ja võib nähtustest luua tegelikkusega võrreldes lihtsustatud mudeleid. Hoiduda tuleks siiski nende mudelite pidamisest tegelikkuseks.

Kõike arvesse võttes tundub ühest küljest, et kui kõnesüntesaator on mõeldud järgima suhtlejate kooperatiivsuse printsiipi, siis peaks ta püüdma kuulajale vastu tulla ning varustama etteloetava teksti sisuga kooskõlas oleva prosoodiaga. Teisest küljest ei näi teatud kõrvalekalded sisu ja prosoodilise väljenduse vahel teksti mõistmisel siiski liiga suureks takistuseks olevat, kuni ei esine kuulajalt liiga suurt lisapingutust nõudvat ilmselget vastuolu. Kuniks ettelugeja intonatsioon on ligilähedane sellele, mida kuulaja eelneva tekstiosa ja peategelase emotsioonide arengu loogika põhjal eeldab, jääb vastuvõtja peas konstrueeritud emotsioonimudel kehtima vähemasti mõne järgneva lause vältel, tekst säilitab emotsionaalse sidususe ja hinnalist töötlusaega ei kaotata. Teksti prosoodiline esitus ei pea seega olema ideaalne, kuid ei tohiks vastuvõttu ja arusaamist emotsionaalse ebaloogilisusega ka segada.

Teksti ettelugemisega seotud isikute, nende perspektiivide ja emotsioonide võimalike lähtekohtade ülevaatus näitas, et nii lugeja kui ka kuulaja on mitte lihtsalt tekstis sisalduva emotsionaalse info vastuvõtjad ja edastajad, vaid selle aktiivsed tõlgendajad, tähenduste ning seoste otsijad.

\section{Viidatud kirjandus}

Altrov, Rene 2007. Emotsionaalse kõne korpuse loomine eesti keele tekst-kõne sünteesi jaoks. Tekstimaterjali evalvatsioon viha näitel. Magistritöö. Tartu Ülikool.

Altrov, Rene 2008. Eesti emotsionaalse kõne korpus: teoreetilised toetuspunktid. - Keel ja Kirjandus, 4, 261-272.

Altrov, Rene; Pajupuu, Hille 2012. Estonian Emotional Speech Corpus: Theoretical base and implementation. - The 4th International Workshop on Corpora for Research on Emotion Sentiment \& Social Signals (ES3), Istanbul. L. Devillers, B. Schuller, A. Batliner, P. Rosso, E, Douglas-Cowie, R. Cowie, C. Pelachaud (Eds.). Istanbul, 50-53.

Altrov, Rene; Pajupuu, Hille; Pajupuu, Jaan; Tamuri, Kairi 2012. Kõne ja teksti emotsionaalsuse statistilised mudelid. - Ettekanne riikliku programmi "Eesti keeletehnoloogia 2011-2017" konverentsil 2.-3. oktoobril Tartus, AHHAA keskuses. http://www. keeletehnoloogia.ee/konverentsid/ekt-esimene-konverents/EKT1.pdf (3.9.2013).

Baron-Cohen, Simon 2003. The Essential Difference: Men, Women and the Extreme Male Brain. Penguin/Basic Books.

Bednarek, Monika 2008. Emotion Talk Across Corpora. Houndmills, New York: Palgrave Macmillan. http://dx.doi.org/10.1057/9780230285712

Caffi, Claudia; Janney, Richard W. 1994. Towards a pragmatics of emotive communication. - Journal of Pragmatics, 22 (3-4), 325-373. http://dx.doi.org/10.1016 /0378-2166(94)90115-5

Conrad, Susan; Biber, Douglas 200o. Adverbial marking of stance in speech and writing. Susan Hunston, Geoffrey Thompson (Eds.). Evaluation in Text. Oxford: Oxford University Press, 56-73.

Currie, Gregory 1998. Realism of character and the value of fiction. - Jerrold Levinson (Ed.). Aesthetics And Ethics: Essays at the Intersection. Cambridge: Cambridge University Press, 161-181. 
de Waal, Frans 2009. The Age of Empathy. Harmony Books.

de Vega, Manuel; Inmaculada, Leon; Diaz, Jose M. 1996. The representation of changing emotions in reading comprehension. - Cognition and Emotion, 10 (3), 303-321. http://dx.doi.org/10.1080/026999396380268

Gernsbacher, Morton A.; Robertson, Rachel W. 1992. Knowledge activation versus sentence mapping when representing fictional characters' emotional states. - Language and Cognitive Processes, 7 (3-4), 353-371. http://dx.doi.org/10.1080/ 01690969208409391

Gerrig, Richard J. 1993. Experiencing Narrative Worlds: On The Psychological Activities Of Reading. New Haven, CT, London: Yale University Press.

Gygax, Pascal; Oakhill, Jane; Garnham, Alan 2003. The representation of characters' emotional responses: Do readers infer specific emotions? - Cognition and Emotion, 17 (3), 413-428. http://dx.doi.org/10.1080/02699930244000048

Kahneman, Daniel 2011. Thinking, Fast and Slow. London: Allen Lane.

Karlgren, Jussi; Sahlgren, Magnus; Olsson, Fredrik; Espinoza, Fredrik; Hamfors, Ola 2012. Usefulness of sentiment analysis. - Ricardo Baeza-Yates (Ed.). ECIR 2012, LNCS 7224. Berlin, Heidelberg: Springer-Verlag, 426-435.

Keen, Suzanne 2006. A theory of narrative empathy. - Narrative, 14 (3), 207-236. http:// dx.doi.org/10.1353/nar.2006.0015

Mihkla, Meelis; Hein, Indrek; Kalvik, Mari-Liis; Kiissel, Indrek; Sirts, Risto; Tamuri, Kairi 2012. Estonian speech synthesis: Applications and challenges. - Andrej Kibrik (Ed.). Computational Linguistics and Intellectual Technologies. Papers from the Annual International Conference "Dialogue". Moskva: РГГУ, 443-453.

Molinari, Carlos; Burin, Débora; Saux, Gastón; Barreyro, Juan P.; Irrazabal, Natalia; Bechis, María S.; Aníbal, Duarte; Verónica, Ramenzoni 2009. Fictional characters' emotional state representation: What is its degree of specificity? - Psicothema, 21 (1), 9-14.

Montag, Christiane; Gallinat, Jürgen; Heinz, Andreas 2008. Theodor Lipps and the Concept of Empathy: 1851-1914. - American Journal of Psychiatry, 165 (10), 1261. http:// dx.doi.org/10.1176/appi.ajp.2008.07081283

Myyry, Liisa; Helkama, Klaus 2007. Socio-cognitive conflict, emotions and complexity of thought in real-life morality. - Scandinavian Journal of Psychology, 48 (3), 247-259. http://dx.doi.org/10.1111/j.1467-9450.2007.00579.x

Osgood, Charles E.; Suci, George J.; Tannenbaum, Percy H. 1975 [1957]. The Measurement of Meaning. Urbana, Chicago: University of Illinois Press.

Pajupuu, Hille; Kerge, Krista; Altrov, Rene 2012. Lexicon-based detection of emotion in different types of texts: preliminary remarks. - Eesti Rakenduslingvistika Ühingu aastaraamat, 8, 171-184. http://dx.doi.org/10.5128/ERYa8.11

Paulmann Silke; Ott, Derek; Kotz, Sonja A. 2011. Emotional speech perception unfolding in time: The role of the basal ganglia. - PLoS ONE, 6 (3), e17694. http://dx.doi. org/10.1371/journal.pone.0017694

Pell, Mark D.; Jaywant, Abishek; Monetta, Laura; Kotz, Sonja A. 2011. Emotional speech processing: Disentangling the effects of prosody and semantic cues. - Cognition and Emotion, 25 (5), 834-853. http://dx.doi.org/10.1080/02699931.2010.516915

Reilley, Judy; Seibert, Laura 2003. Language and emotion. - Richard J. Davidson, Klaus R. Scherer, Hill H. Goldsmith (Eds.). Handbook of Affective Sciences. Oxford University Press, 535-559.

Rimmon-Kenan, Shlomith 2002. Narrative Fiction: Contemporary Poetics. London, New York: Routledge.

Sklar, Howard 2009. Believable fictions: On the nature of emotional responses to fictional characters. - Helsinki English Studies 5. Electronic Journal. http://blogs.helsinki.fi/ hes-eng/volumes/volume-5/ (4.9.2013). 
Sutrop, Margit 1999. Sympathy, imagination, and the readers' emotional response to fiction. - Jürgen Schlaeger (Ed.). Representations of Emotions. Tübingen: Gunter Narr Verlag, 29-42.

Tamuri, Kairi 2013. Emotsioonide akustika ja nende mudeldamine. - Ettekanne Keeleteaduse, Filosoofia ja Semiootika Doktorikooli (KFSDK) sügisseminaril "Kõnetehnoloogiast filoloogile”, 13.9.2013. https://dl.dropboxusercontent.com/u/33219645/Sangaste\%2O 2013/Kairi\%20Tamuri_2013.pdf (6.1.2014).

Ungerer, Friedrich 1997. Emotions and emotional language in English and German news stories. - S. Niemeier, R. Dirven (Eds.). The Language of Emotions. Conceptualization, Expression, and Theoretical Foundation. Amsterdam, Philadelphia: John Benjamins, 307-329.

Vainik, Ene 2002. Emotions, emotion terms and emotion concepts in an Estonian folk model. - Trames: Journal of the Humanities and Social Sciences, 6 (4), 322-341.

Vainik, Ene 2010. Kuidas õpetada kõnesüntesaatorile empaatiat? Emotsiooni automaatse tuvastuse võimalustest eestikeelses kirjalikus lauses sisalduva info põhjal. - Eesti Rakenduslingvistika Ühingu aastaraamat, 6, 327-347. http://dx.doi.org/10.5128/ ERYa6.20

Vainik, Ene 2012a. Eesti keele sõnavara afektikalduvus ja mis sellega peale hakata. - Keel ja Kirjandus, 8-9, 644-657.

Vainik, Ene 2012b. Kuidas määrata eesti keele sõnavara tundetoone? - Eesti Rakenduslingvistika Ühingu aastaraamat, 8, 257-274. http://dx.doi.org/10.5128/ERYa8.17

Vogt, Thurid; Andre, Elisabeth; Wagner, Johannes 2008. Automatic recognition of emotions from speech: A review of the literature and recommendations for practical realisation. - Christian Peter, Russell Beale (Eds.). Affect and Emotion in Human-Computer Interaction, LNCS 4868. Heidelberg: Springer, 75-91.

Walton, Kendall 1990. Mimesis As Make-Believe: On the Foundations of the Representational Arts. Cambridge, MA: Harvard University Press.

\section{Võrguaadressid}

Eesti emotsionaalse kõne korpus. http://peeter.eki.ee:500o/ (22.9.2013).

Eesti Keele Instituudi emotsioonidetektor. http://peeter.eki.ee:500o/valence (22.9.2013).

Eesti keeletehnoloogia konverentside veebiväljaanne. http://www.keeletehnoloogia.ee/ konverentsid/ekt-esimene-konverents/EKT1.pdf (3.9.2013).

Eesti Päevalehe veebiväljaanne. http://www.epl.ee/news/eesti/igor-grazin-peab-err-iuudiste-tooni-lubamatuks.d?id=65327458) (22.9.2013).

Keeleteaduse, Filosoofia ja Semiootika Doktorikooli (KFSDK) materjalid. http://portaal.eki. ee/tegevusvaldkonnad/246.html (12.12.2012).

Rahvusvaheline Psühhiaatria kuukiri. http://ajp.psychiatryonline.org/data/Journals/ AJP/3872/o8aj1261.PDF (12.12.2012).

Tallinna Ülikooli pedagoogilise seminari abimaterjalid. http://www.teatoimeta.ee/Lea_ Nurkse_1904-1960_288.htm (13.9.2013).

Ene Vainiku (Eesti Keele Instituut) uurimisalaks on kognitiivne lingvistika, semantika ning keele ja emotsioonide vastasseosed. Avaldanud uurimusi emotsiooninimetustest, piltlikest ja dünaamilistest emotsioonikirjeldustest ning emotsiooni eestikeelses tekstis tuvastamise problemaatikast.

Roosikrantsi 6, 10119 Tallinn, Estonia

Ene.Vainik@eki.ee 


\title{
WHO'S EMOTIONS TO EXPRESS WHILE READING OUT LOUD? A MULTI-PERSPECTIVE APPROACH
}

\author{
Ene Vainik
}

Institute of the Estonian Language

Human emotions is one of the aspects that accounts for the desired goal of humanlikeness of text-to-speech synthesis. Present article tackles the question to whose emotions give the opportunity to be expressed in voice? Should it be the Author of the text, the Protagonist or someone else? Literature from different disciplines (psychology, literary science, philosophy, affective computing etc.) is used to shed light on the issue.

As regards to the perspective of the potential listener - the ultimate consumer of the text-to-speech service - the literature confirms the intuition that emotional prosody will facilitate understanding, by activating the emotional aspects in the listener's memory, supposedly. The role of emotional prosody is found to be bigger in the case of neutrality or ambivalence of the semantic content of the sentences.

As regards to the emotions of the persons potentially represented in the text - the Protagonist and the Author - it revealed that the readers use to construct a dynamic representation of the Protagonist's emotions in their minds. The emotional attitude of the Author may be recognized from the involved (subjective) vs. uninvolved (objective) type of focalizing. In the case the text is written in the 1st person's perspective, the Author and the Protagonist (and their emotions) coincide, supposedly. The emotional information is processed in a sequential order as it unfolds in the narrative. Generally, the readers have an expectation for the emotional model to be "logical". Processing "illogical" emotional information, while presented, takes extra processing cost.

There appears to be a lot of theorizing in the literature in respect of the emotions of the reader of the text. Besides empathy as an explanation for this phenomenon, also multimodal simulation and emotional inferences from some textual cues have been offered, among others. The latter approach relies on the three dimensions of the semantic/emotional space (well known from psycholinguistics): evaluation, activation, and potency.

While a human being - a layman - has the task to read out loud a text unfamiliar to him/her with an appropriate emotional prosody, it takes some effort, too. Analysis of the empirical data from the Estonian Emotional Speech Corpus suggests, that in half of the instances the laymen tended to express their own emotions towards the semantic content of the text rather than to empathize with the main character or the author of the text.

The different persons and perspectives represented in the text are not accounted for in the field of affective computing, yet. Instead, the readers' expected reaction is attributed to the text as it's measure of "emotionality" and is supposed to be applicable as an instruction for the synthesizer while mimicking human emotional prosody.

Keywords: written text, synthesized speech, emotions, affective computing, multiplicity of perspectives, Estonian language 